\title{
Lysate of engineered Escherichia coli supports high-level conversion of glucose to 2,3-butanediol
}

\author{
Jennifer E. Kay ${ }^{1,2}$ and Michael C. Jewett ${ }^{1,2,3,4^{*}}$
}

${ }^{1}$ Department of Chemical and Biological Engineering, ${ }^{2}$ Chemistry of Life Processes Institute, Northwestern University, Evanston, IL 60208, USA

${ }^{3}$ Robert H. Lurie Comprehensive Cancer Center, ${ }^{4}$ Simpson Querrey Institute Northwestern University, Chicago, IL 60611, USA

${ }^{*}$ Correspondence: Michael C. Jewett, Department of Chemical and Biological Engineering, Northwestern University, Evanston, IL 60208, USA

E-mail addresses: m-jewett@northwestern.edu

Tel: 1847467 5007; Fax: 18474913728 


\section{Abstract}

Cell-free metabolic engineering (CFME) is emerging as a powerful approach for the production of target molecules and pathway debugging. Unfortunately, high cofactor costs, limited cofactor and energy regeneration, and low volumetric productivities hamper the widespread use and practical implementation of CFME technology. To address these challenges, we have developed a cell-free system that harnesses ensembles of catalytic proteins prepared from crude lysates, or extracts, of cells to fuel highly active heterologous metabolic conversions. As a model pathway, we selected conversion of glucose to 2,3-butanediol (2,3-BD), a medium level commodity chemical with many industrial applications. Specifically, we engineered a single strain of Escherichia coli to express three pathway enzymes necessary to make meso-2,3-BD (m2,3-BD). We then demonstrated that lysates from this strain, with addition of glucose and catalytic amounts of cofactors NAD+ and ATP, can produce m2,3-BD. Endogenous glycolytic enzymes convert glucose to pyruvate, the starting intermediate for m2,3-BD synthesis. Strikingly, with no strain optimization, we observed a maximal synthesis rate of $\mathrm{m} 2,3-\mathrm{BD}$ of $11.3 \pm 0.1 \mathrm{~g} / \mathrm{L} / \mathrm{h}$ with a theoretical yield of $71 \%(0.36 \mathrm{~g} \mathrm{~m} 2,3-\mathrm{BD} / \mathrm{g}$ glucose) in batch reactions. Titers reached $82 \pm 8 \mathrm{~g} / \mathrm{L} \mathrm{m2,3-BD}$ in a 30 hour fed-batch reaction. Our results highlight the ability for high-level co-factor regeneration in cell-free lysates. Further, they suggest exciting opportunities to use lysate-based systems to rapidly prototype metabolic pathways and carry out molecular transformations when bioconversion yields (g product/L), productivities (g product $/ \mathrm{L} / \mathrm{h}$ ), or cellular toxicity limit commercial feasibility of whole-cell fermentation. 
Keywords: cell-free metabolic engineering, cell-free synthetic biology, 2,3-butanediol, Escherichia coli, in vitro, cofactor regeneration 


\section{Introduction}

Humans have opportunistically leveraged the metabolic activity of other species for thousands of years. Some of the oldest examples include use of yeasts and bacteria in leavening and fermenting foods and the use of prepared plant parts as medicine. More recently, our ability to engineer living organisms by optimizing genetic and regulatory processes has widened the aperture to new metabolic engineering applications in chemical manufacturing, environmental remediation, materials production and pharmaceutical synthesis, among others (Bond-Watts et al., 2011; Burgard et al., 2011; Gronenberg et al., 2013; Lee et al., 2012; Nakamura and Whited, 2003; Paddon et al., 2013).

While the number of microbial metabolic engineering success stories is rapidly growing, generating high flux through a novel pathway can still be costly and difficult (Kern et al., 2007; Kwok, 2010). Development of processes to make target products, such as artemisinin, farnesene, and 1,3-propanediol, have historically required hundreds of person years of work (Hodgman and Jewett, 2012). Common challenges afflicting the state-of-the-art include low volumetric productivities $(\mathrm{g} / \mathrm{L} / \mathrm{hr})$, build-up of toxic intermediates or products, byproduct losses via competing pathways, and constraints that arise from the conflict between microbial health and flux towards a single product. Further, the chemical reactions that engineers seek to control take place behind a selective barrier, the cell wall, which limits sample acquisition, monitoring, and direct control of reaction components. 
These challenges motivate the need for new tools to more fully access the powerful synthetic and functional capabilities of biology. The growing field of synthetic biology offers new advanced tools and generalized capabilities to modify living organisms for process engineering objectives (Nielsen et al., 2014). Within synthetic biology, cell-free metabolic engineering (CFME) is emerging as a high yielding strategy to implement in vitro ensembles of catalytic proteins, prepared from purified enzymes or crude lysates of cells, for manufacturing target products, prospecting novel biosynthetic pathways, and rapidly prototyping metabolism.

CFME complements in vivo efforts, and has grown over the past decade to become a powerful platform to understand, harness, and expand the capabilities of natural biological systems (Billerbeck et al., 2013; Dudley et al., 2015; Guterl et al., 2012; Rollin et al., 2013; Swartz, 2012; Welch and Scopes, 1985). CFME offers exciting potential advantages. From a biomanufacturing perspective, cell-free systems separate catalyst synthesis (cell growth) from catalyst utilization (metabolite production). This concept represents a significant departure from cell-based processes that rely on microscopic cellular 'reactors'. Further, cell-free systems avoid toxicity constraints. Additionally, the open environment of the reaction allows the user to directly influence biochemical systems of interest. As a result, new components can be added or synthesized and can be maintained at precise concentrations, while the chemical environment is easily monitored and sampled (Carlson et al., 2012; You and Zhang, 2013). From a prototyping perspective, cell-free systems are particularly well suited to rapid designbuild-test cycles because they do not require the re-engineering of genetic pathways in 
organisms with each design (Bujara et al., 2010; Chappell et al., 2015; Karig et al., 2012; Shin and Noireaux, 2012; Sun et al., 2014; Takahashi et al., 2014). There is also a high degree of flexibility to model individual enzyme kinetics, measure metabolite fluxes in multistep pathways, determine catalyst stability, study the effects of redox potential on pathway performance, and experimentally isolate many other process properties that are confounded in living organisms.

Despite these advantages, most industrial use in cell-free systems to date has been for applications that require very few enzymatic steps and no cofactors. The bulk of the $\sim \$ 5$ billion world enzyme market goes towards simple isomerization or thermodynamically favorable breakdown of biological structures such as lipids and polysaccharides (Adrio and Demain, 2014; Li et al., 2012; Sanchez and Demain, 2011). More complex systems of purified enzymes have been demonstrated in academic labs (Dudley et al., 2015), including the pioneering work of Welch and Scopes (1985), but several obstacles have in general prevented economic scaling, including low volumetric productivities ( $g / L / h)$, high cofactor costs, limited ability to regenerate cofactors and energy (e.g., 2-18 NAD/H turnovers in recent studies (Dudley et al., 2015)), and high catalyst costs relative to their usable lifetime (Sanchez and Demain, 2011).

Here, rather than using purified enzyme systems, we sought to assess the possibility to activate long native pathways in crude cell extracts of Escherichia coli to regenerate cofactors and energy to provide the support system necessary to fuel highly active heterologous metabolic conversions. Over the last decade, researchers in crude extract 
based cell-free protein synthesis (CFPS) systems have established enabling technologies in which integrated metabolic functions such as central metabolism and the TCA cycle can be activated and controlled in cell-free extracts (Calhoun and Swartz, 2005; Caschera and Noireaux, 2014; Caschera and Noireaux, 2015; Jewett et al., 2008; Jewett and Swartz, 2004). If cofactor and energy regenerating systems in crude extract can be activated for cell-free protein synthesis, we hypothesized that they could also be activated to support a highly active exogenous pathway.

We aimed to test this concept using a short exogenous pathway for the production of 2,3-butanediol (2,3-BD) that requires the cofactor $\mathrm{NADH}$. 2,3-BD is a medium level commodity chemical with applications in the manufacture of inks, explosives, perfumes, resins, polymers, paint, flavorings, and pharmaceuticals (Ji et al., 2011; Kopke et al., 2011). It is difficult to chemically synthesize a single chiral form or to separate multiple isomers, so biological pathways that produce only one isoform are desirable ( $\mathrm{Ji}$ et al., 2011; Kopke et al., 2011). For our purposes, it was an ideal initial target because it can be converted from pyruvate, a key node in central metabolism, in only three steps requiring the use of one cofactor. In addition, E. coli does not naturally produce 2,3-BD, but multiple exogenous pathways have been demonstrated at the gram per liter scale (Ji et al., 2014; Nielsen et al., 2010; Xu et al., 2014; Yan et al., 2009).

In this work, we used traditional molecular cloning and protein expression techniques to create strains of $E$. coli with heterologous pathways for 2,3-BD from pyruvate. We used these strains to produce large batches of bacterial crude cell lysate containing all 
enzymes necessary to convert glucose to $2,3-\mathrm{BD}$. The lysates were combined with salts, catalytic cofactors, and glucose and assayed for production of 2,3-BD. We show that the native E. coli glycolytic enzymes naturally present in lysate can convert glucose to pyruvate, which is then available to three exogenously expressed enzymes to convert to 2,3-BD. Native E. coli enzymes must also recycle NAD+ to NADH to allow observed accumulation of the product. After demonstrating 2,3-BD synthesis, metabolite profiling of the CFME reactions was conducted to determine what limits the system. We observed that substrate (glucose) depletion was chiefly responsible for reaction termination. Fed-batch replenishment of glucose prolonged the reaction duration to achieve the production of 2,3-BD with high yield ( $82 \pm 8 \mathrm{~g} / \mathrm{L})$ and productivity $(2.7 \mathrm{~g} / \mathrm{L} / \mathrm{h})$.

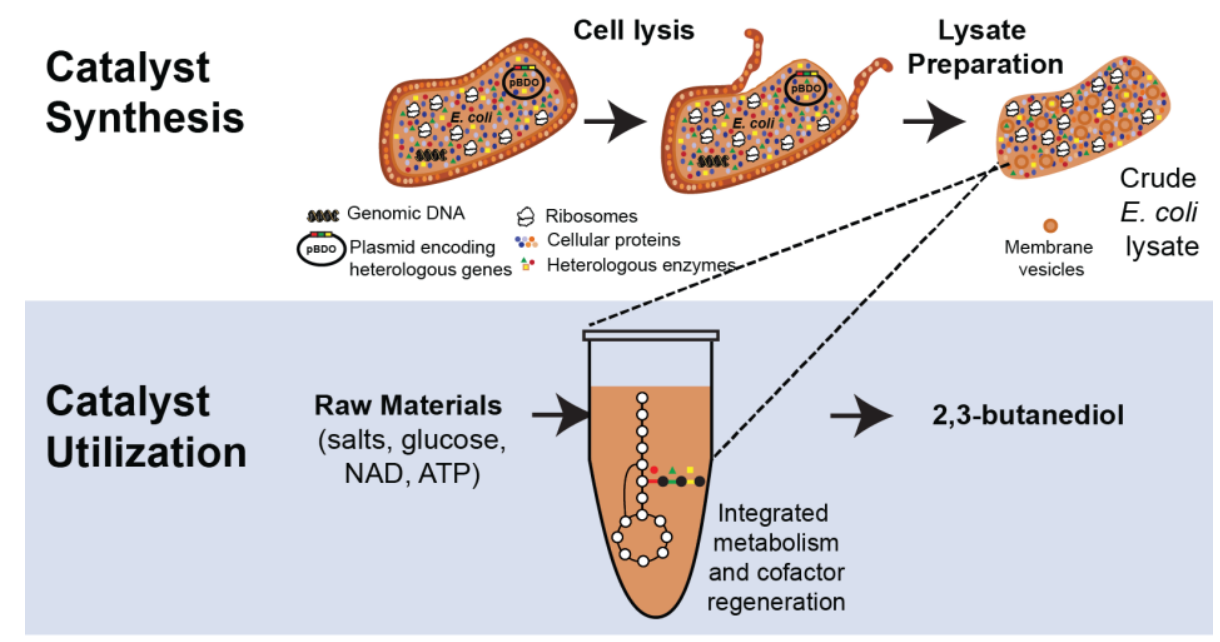

Figure 1. A general workflow for pathway activation in cell-free lysates. The extracts convert glucose to pyruvate, providing the starting intermediate for 2,3-BD biosynthesis. 


\section{Materials and Methods}

\subsection{Chemicals}

BD Bacto ${ }^{\mathrm{TM}}$ brand media components tryptone and yeast extract were obtained from BD Biosciences (San Jose, CA). Carbenicillin was obtained from IBI Scientific (Peosta, IA) and isopropyl- $\beta$-D-thiogalactoside (IPTG) from Santa Cruz Biotechnology (Dallas, TX). All DNA-modifying enzymes and polymerases were purchased from New England Biolabs (NEB) (Ipswich, MA). All other reagents are analytical grade purchased from Sigma Aldrich (St. Louis, MO).

\subsection{Strains \& vectors}

The strains used for this study are listed in Table 1. E. coli NEB $5 a$ or Turbo ${ }^{\text {TM }}$ (NEB) were used for routine cloning and BL21(DE3) was used for fermentation and extract preparation. Constructs from previous studies were used with permission for initial screening purposes and as gene templates to construct plasmids suited to cell-free extract production. Plasmid pZE12-alsS-alsD-BudC was used as the template for genes for ALS and ALDC from Bacillus subtilis and BDH from Klebsiella pneumoniae (Yan et al., 2009) and the gene for ALS from E. coli was lifted from pET-ilvBNEc-aldBLI (Nielsen et al., 2010). 
Table 1. Strains and plasmids used in this study. $A m p^{R}$ is ampicillin resistance.

\section{Strains and plasmids}

\section{E. coli strains}

NEB $5 \alpha$

NEB Turbo

BL21(DE3)

Plasmids

pUC19

pUCBCS

pET22b

pETBCS

pZE12-alsS-alsD-BudC

pET-ilvBNEc-aldBLI

pETBCS-ilvBN-aldB-butB

pETBCS-alsS-alsD-budC
Relevant genotype

Source

fhuA2 $\Delta$ (argF-lacZ)U169 phoA glnV44 $\$ 80 \Delta$ (lacZ)M15

gyrA96 recA1 relA1 endA1 thi-1 hsdR17

NEB

$F^{\prime}$ proA $^{+} B^{+}$lacl $\triangle$ lacZM15 / fhuA2 $\triangle$ (lac-proAB) glnV galK16

galE15 $R(z g b-210:: T n 10) T e t^{S}$ endA1 thi-1 $\Delta$ (hsdS-mcrB)5 NEB

fhuA2 [lon] ompT gal ( $\lambda$ DE3) [dcm] $\Delta h s d S$

NEB

$\lambda$ DE3 $=\lambda$ sBamHlo $\triangle E$ coRI-B int::(lacl::PlacUV5::T7 gene1)

i21 $\Delta$ nin5

\begin{tabular}{|c|c|}
\hline pMB1 ori, $\mathrm{Amp}^{\mathrm{R}}$ & NEB \\
\hline pUC19 with modified multiple cloning site (Supplement) & This study \\
\hline ColE1(pBR322) ori, lacl, T7lac, Amp ${ }^{\mathrm{R}}$ & Novagen \\
\hline $\begin{array}{l}\text { pET22b with signal sequence removed and modified } \\
\text { restriction sites (Supplement) }\end{array}$ & This study \\
\hline Used as template for alsS, alsD, and budC & $\begin{array}{l}\text { (Yan et al., } \\
\text { 2009) }\end{array}$ \\
\hline Used as template for ilvBN & $\begin{array}{l}\text { (Nielsen et } \\
\text { al., 2010) }\end{array}$ \\
\hline $\mathrm{P}_{\mathrm{T} 7}:: i l v B N$, ald $B$, butB & This study \\
\hline $\mathrm{P}_{\mathrm{T} 7}:: a l s S$, alsD, budC & This study \\
\hline
\end{tabular}

Table 2. Sources of genes selected for extract source strains to produce m2,3-BD and R,R-2,3-BD.

\begin{tabular}{clccc} 
Enzyme & \multicolumn{2}{c}{ R,R-2,3-BD pathway } & \multicolumn{2}{c}{ m2,3-BD pathway } \\
& gene & species & gene & species \\
\hline acetolactate synthase (ALS) & ilvBN & E. coli & alsS & B. subtilis \\
acetolactate decarboxylase (ALDC) & aldB & L. lactis & alsD & B. subtilis \\
2,3-butanediol dehydrogenase (BDH) & butB & L. lactis & budC & K. pneumoniae
\end{tabular}

\subsection{Cloning}

Constructs used in this study were assembled using the Berkeley cloning standard (Anderson et al., 2010) and Gibson assembly (Gibson et al., 2009). The multiple cloning site (MCS) of pUC19 was modified to the standard and used for propagation of DNA 
and initial assembly steps. The MCS of $\mathrm{pET}-22 \mathrm{~b}$ purchased from Novagen/EMD Millipore was similarly modified and the signal sequence removed. Details of these modifications are found in the supplement. Most genes used in the study were amplified from existing constructs, except for those encoding ALDC and BDH from Lactococcus lactis which were ordered, with internal restriction sites removed by changing for equivalent codons, as gBlocks from IDT and cloned into pUCBCS by Gibson assembly. Ribosome binding sites (RBS) were designed using the Salis RBS calculator (Salis, 2011) and introduced via annealed primers. Operons of RBS and genes were then ligated into the modified $\mathrm{pET}-22 \mathrm{~b}$ vector for expression and extract production. The genes in all final constructs have been sequence confirmed. Expression of genes was confirmed via SDS-PAGE gel electrophoresis (Supplementary Figure 1). Sequences of gBlocks and modified MCS are found in the cloning section of the supplement.

\subsection{Extract preparation}

S30 extract was prepared by first growing BL21(DE3) cells carrying either pETBCSalsS-alsD-budC or pETBCS-ilvBN-aldB-butB to $\mathrm{OD}_{600 \mathrm{~nm}}$ of 0.6 in $1 \mathrm{~L} 2 \mathrm{xYTPG}$ media (16 $\mathrm{g} \cdot \mathrm{L}^{-1}$ tryptone, $10 \mathrm{~g} \cdot \mathrm{L}^{-1}$ yeast extract, $5 \mathrm{~g} \cdot \mathrm{L}^{-1} \mathrm{NaCl}, 7 \mathrm{~g} \cdot \mathrm{L}^{-1}$ potassium phosphate monobasic, $3 \mathrm{~g} \cdot \mathrm{L}^{-1}$ potassium phosphate dibasic, $18 \mathrm{~g} \cdot \mathrm{L}^{-1}$ glucose) in $2.5 \mathrm{~L}$ Tunair ${ }^{\mathrm{TM}}$ flasks at $37^{\circ} \mathrm{C}$ and $250 \mathrm{rpm}$. To express the exogenous enzymes, cells were incubated for an additional four hours at $30{ }^{\circ} \mathrm{C}$ with $0.1 \mathrm{mM}$ IPTG. Cells were harvested by centrifugation at $8000 \times g$ and $4{ }^{\circ} \mathrm{C}$ for 15 minutes. The cell pellet was rinsed twice with S30 buffer $(10 \mathrm{mM}$ tris acetate $\mathrm{pH} 8.2,14 \mathrm{mM}$ magnesium acetate, and $60 \mathrm{mM}$ potassium acetate), flash frozen in liquid nitrogen, and stored at $-80^{\circ} \mathrm{C}$ until lysis. To 
lyse, cells were thawed, suspended in an additional $0.7 \mathrm{~mL} \$ 30$ buffer per gram wet cell pellet, and lysed at 20,000 PSIG using an EmulsiFlex-C3 homogenizer (Avestin, Ottawa, ON). The lysate was clarified twice by centrifugation at $30,000 \times g$ and $4{ }^{\circ} \mathrm{C}$ for 30 minutes, then stored in aliquots at $-80{ }^{\circ} \mathrm{C}$ until use. Protein concentration was determined by Bradford assay with BSA standard.

\subsection{In vivo fermentation control}

While the goal of this study was to demonstrate a new technological approach for CFME, and not to design an engineered strain for best fermentative production of 2,3BD in cells (which has been thoroughly explored elsewhere (Xu et al., 2014)), we did carry out shake-flask cultivation in vivo. Time course experiments were carried out comparing the BL21 strains harboring the 2,3-BD production pathway plasmids used to produce extract for this study. Specifically, cultivations were carried out in $1 \mathrm{~L}$ of $2 x$ YTPG liquid medium (the same used to generate cells for S30 extract generation) in 2.5 Tunair ${ }^{\mathrm{TM}}$ shake flasks at $37^{\circ} \mathrm{C}$. As in production of $\mathrm{S} 30$ extract, expression was induced with $0.1 \mathrm{mM}$ IPTG at $\mathrm{OD}_{600 \mathrm{~nm}}$ of 0.6 and temperature reduced to $30^{\circ} \mathrm{C}$. To sample the supernatant for 2,3-BD, acetoin, and other organic acids, cells were removed by centrifugation at $15,000 \times g$ and $4^{\circ} \mathrm{C}$ for 1 minute and the supernatant filtered to $0.2 \mu \mathrm{m}$ and stored at $-80^{\circ} \mathrm{C}$ until analysis by HPLC.

\subsection{Cell-free reactions}

Reactions were carried out in $1.5 \mathrm{~mL}$ Eppendorf tubes at $37^{\circ} \mathrm{C}$ in $25 \mu \mathrm{L}$ volumes. Reaction components were added to final concentrations according to Table 3 unless 
otherwise noted. Reactions were stopped by addition of $0.2 \mathrm{M}$ sulfuric acid. Precipitated protein was removed by centrifugation at $10,000 \times g$ for 10 minutes, after which the supernatant was stored at $-80^{\circ} \mathrm{C}$ until analysis by HPLC.

Table 3. Standard reaction concentrations with pyruvate or glucose as substrate.

\begin{tabular}{lc|lc}
\hline Pyruvate system & $(\mathbf{m M})$ & Glucose system & $(\mathbf{m M})$ \\
\hline magnesium glutamate & 12 & magnesium glutamate & 12 \\
ammonium glutamate & 10 & ammonium glutamate & 10 \\
potassium glutamate & 130 & potassium glutamate & 130 \\
& & potassium phosphate $\mathrm{pH} 7.2$ & 10 \\
sodium pyruvate & 50 & glucose & $100-1000$ \\
NAD & 1 & NAD & 1 \\
S30 extract & $13 \mathrm{mg} / \mathrm{mL}$ & ATP & 1 \\
magnesium acetate & 4.6 & S30 extract & $13 \mathrm{mg} / \mathrm{mL}$ \\
potassium acetate & 19.5 & magnesium acetate & 4.6 \\
tris acetate & 3.3 & potassium acetate & 19.5 \\
& & tris acetate & 3.3 \\
\hline
\end{tabular}

Note: All values are given in $\mathrm{mM}$ except the extract total protein concentration.

\subsection{Chromatography}

High-performance liquid chromatography (HPLC) was used to measure components present in the cell-free reactions and in growth media during fermentation. Glucose, acetate, lactate, ethanol, pyruvate, succinate, formate, acetoin and 2,3-BD were quantified using an Agilent 1260 series HPLC system equipped with a refractive index detector (Agilent, Santa Clara, CA) with an Aminex HPX 87-H column (Bio-Rad, Hercules, CA). Typically an isocratic flow of $0.6 \mathrm{~mL} \cdot \mathrm{min}^{-1}$ of $5 \mathrm{mM}$ sulfuric acid at $55^{\circ} \mathrm{C}$ for 25 minutes was used. Once it was determined that each extract was making only 
one isomer of 2,3-BD (see Supplementary Methods), the method was optimized for best separation of each isomer. To achieve better resolution of acetoin and meso-2,3-BD, clarified cell-free reactions were analyzed at $0.55 \mathrm{~mL} \cdot \mathrm{min}^{-1}$ and $35^{\circ} \mathrm{C}$. Quantification of $\mathrm{R}, \mathrm{R}-2,3-\mathrm{BD}$ was performed at $0.6 \mathrm{~mL} \cdot \mathrm{min}^{-1}$ and $60{ }^{\circ} \mathrm{C}$. Concentrations were determined by comparison to a standard calibration. $R, R-2,3-B D$ was differentiated from S,S-2,3-BD by comparison to standards on GC-MS using a chiral column, details of which are included in the Supplement.

\subsection{Initial rate calculations}

Initial rates were calculated by measuring 2,3-BD concentration at fifteen-minute intervals up to 90 minutes after reaction start. Reaction components were mixed, aliquoted in equal volume to multiple tubes, which were then individually collected and stopped by addition of $0.2 \mathrm{M}$ sulfuric acid at each time point. Each condition used two sets of independently mixed samples. Upon seeing that the entire interval was indeed linear, the regression function from Excel's data analysis add-on was applied to calculate a slope, which is the rate of $2,3-\mathrm{BD}$ production in the extract, and relevant statistics. The error reported for initial rate values is given as the standard error of the estimated slope. 


\section{Results}

With the goal of activating endogenous metabolism in S30 crude extracts to convert glucose to 2,3-BD as a model demonstration (Figure 2), we chose to build-up complexity in three stages. First, we introduced the pathway genes necessary to convert pyruvate to 2,3-BD. Second, we learned to activate cell-free metabolism from glucose. Third, we characterized and alleviated substrate limitations for highly productive cell-free bioconversions.

\subsection{Preparation of E. coli source strains for crude extracts}

Pyruvate is converted to $2,3-\mathrm{BD}$ by three enzymes. First, pyruvate is converted to acetolactate with loss of one unit carbon dioxide by acetolactate synthase (ALS). Then, acetolactate is converted to acetoin by acetolactate decarboxylase (ALDC) with loss of a second unit carbon dioxide. The final step is a reversible conversion to 2,3-BD by 2,3$\mathrm{BD}$ dehydrogenase $(\mathrm{BDH})$ requiring one $\mathrm{NADH}$. 

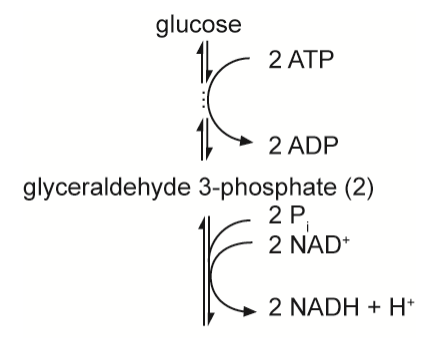

1,3-Bisphosphoglycerate (2)

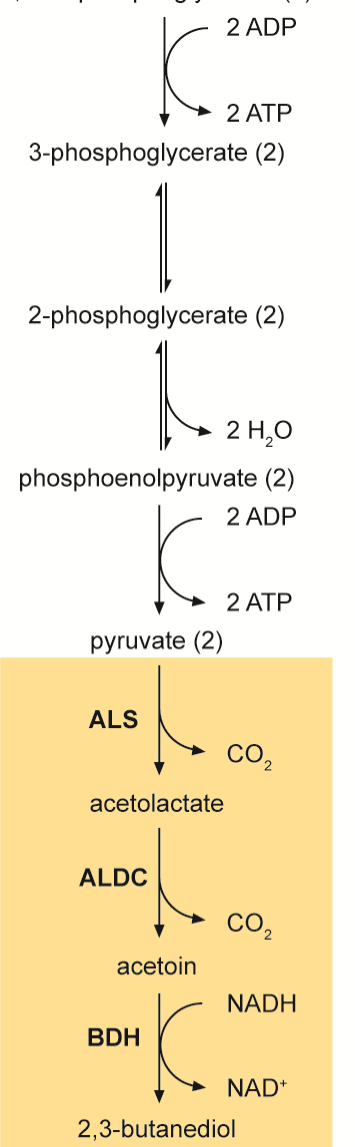

Figure 2. Biosynthetic pathway for production of 2,3-BD from glucose. In our system, cell-free extracts are prepared from E. coli cells that overexpress three heterologous enzymes to convert pyruvate to 2,3-BD (shown in yellow). The extracts convert glucose to pyruvate. The theoretical yield of 2,3-BD from glucose is $1: 1 \mathrm{M}$ or 0.5 $g / g$.

To enable cell-free biosynthesis of 2,3-BD from pyruvate, we first introduced the three enzymes necessary for conversion of pyruvate to $2,3-\mathrm{BD}$ into our extract source strain using a plasmid based expression system (Table 2). Specifically, we cloned individual genes previously demonstrated for 2,3-BD synthesis (Nielsen et al., 2010; Yan et al., 
2009) into plasmid pETBCS using a BglBrick cloning strategy (Anderson et al., 2010). Each plasmid construct contained the entire synthetic pathway for 2,3-BD production as an operon behind T7 promoters and strong ribosome binding sites (RBSs) determined by the RBS calculator (Salis, 2011) to identify a sequence for strong expression in pETBCS with different gene products (i.e., 70,000-280,000 au). We used E. coli strain BL21 (DE3) as the lysate source strain, which contains the DE3 lysogen harboring the T7 RNA polymerase. Our approach allowed us to enrich the BL21 (DE3) source strain with the synthetic pathway based on simple, T7-based overexpression. This is a departure from in vivo efforts that significantly focus on flux balancing and more delicate promoter tuning to maintain viability (Ajikumar et al., 2010; Alper and Stephanopoulos, 2007; Blazeck et al., 2011; Du et al., 2012). This distinction is possible because the in vivo role is simply to enable recombinant expression for enriching lysates with desired pathway catalysts in high concentrations.

After construction of 2,3-BD expression plasmids, we assessed protein overexpression and solubility in our chassis strain using SDS-PAGE analysis. Pathway enzymes were overexpressed in cells induced at $\mathrm{OD}_{600 \mathrm{~nm}}$ of 0.6 and incubated at $30{ }^{\circ} \mathrm{C}$ for 4 hours prior to cell harvesting as described in the methods. As expected, we observed that proteins were overexpressed as the dominant bands on an SDS-PAGE gel (Supplementary Figure 1). In all cases, the majority of overexpressed protein was soluble (Supplementary Figure 1). Notably, in each of the two pathways constructed, for $\mathrm{R}, \mathrm{R}-2,3-\mathrm{BD}$ and $\mathrm{m} 2,3-\mathrm{BD}$ each pathway enzyme was visibly over-expressed. 


\subsection{Cell-free bioconversions of 2,3-BD from pyruvate}

Once protein overexpression was confirmed, we generated crude lysates (termed S30 extracts as they consist of the soluble lysate following a 30,000 $\mathrm{g} g$ centrifugation) from our source strains harvested during mid-exponential growth at $\sim 3 \mathrm{OD}_{600 \mathrm{~nm}}$ following established protocols (Jewett et al., 2008). Following lysis and extract preparation, we assessed the 2,3-BD synthesis activity in $25 \mu \mathrm{L}$ CFME batch reactions carried out for 1 h at $37^{\circ} \mathrm{C}$ via high performance liquid chromatography (HPLC). The contents of the cellfree reactions closely mimicked the physicochemical environment of the cytoplasm, as is common in the CFPS literature. Thus, each batch reaction comprised $\sim 150 \mathrm{mM}$ glutamate salts, $50 \mathrm{mM}$ pyruvate as a substrate, and catalytic amounts of necessary cofactors, such as NAD+ (1mM) (Table 3). The average total protein concentration in each reaction was $13 \pm 1 \mathrm{mg} / \mathrm{mL}$. Samples were taken every 5-15 minutes to profile acetoin and 2,3-BD during the course of the reaction. Extracts selectively enriched with the 2,3BD pathway enzymes for producing either R,R-2,3-BD or m2,3-BD converted $50 \mathrm{mM}$ pyruvate to acetoin and 2,3-BD within minutes (Figure 3A, B). Measurements of pathway intermediates over the course of the $1 \mathrm{~h}$ reaction demonstrated a rapid synthesis of acetoin, which was slowly converted to 2,3-BD. Post synthesis, we verified synthesis of optically active or meso forms of 2,3-BD by chromatography methods (see Supplementary Figures $2 \& 3$ and Supplementary Methods). Collectively, our results validated our approach for enriching crude extracts by overexpressing heterologous pathway genes necessary to convert pyruvate to 2,3-BD. As expected, a negative control reaction performed using BL21 extracts that did not contain the plasmid harboring the biosynthetic pathway enzymes did not produce 2,3-BD. 

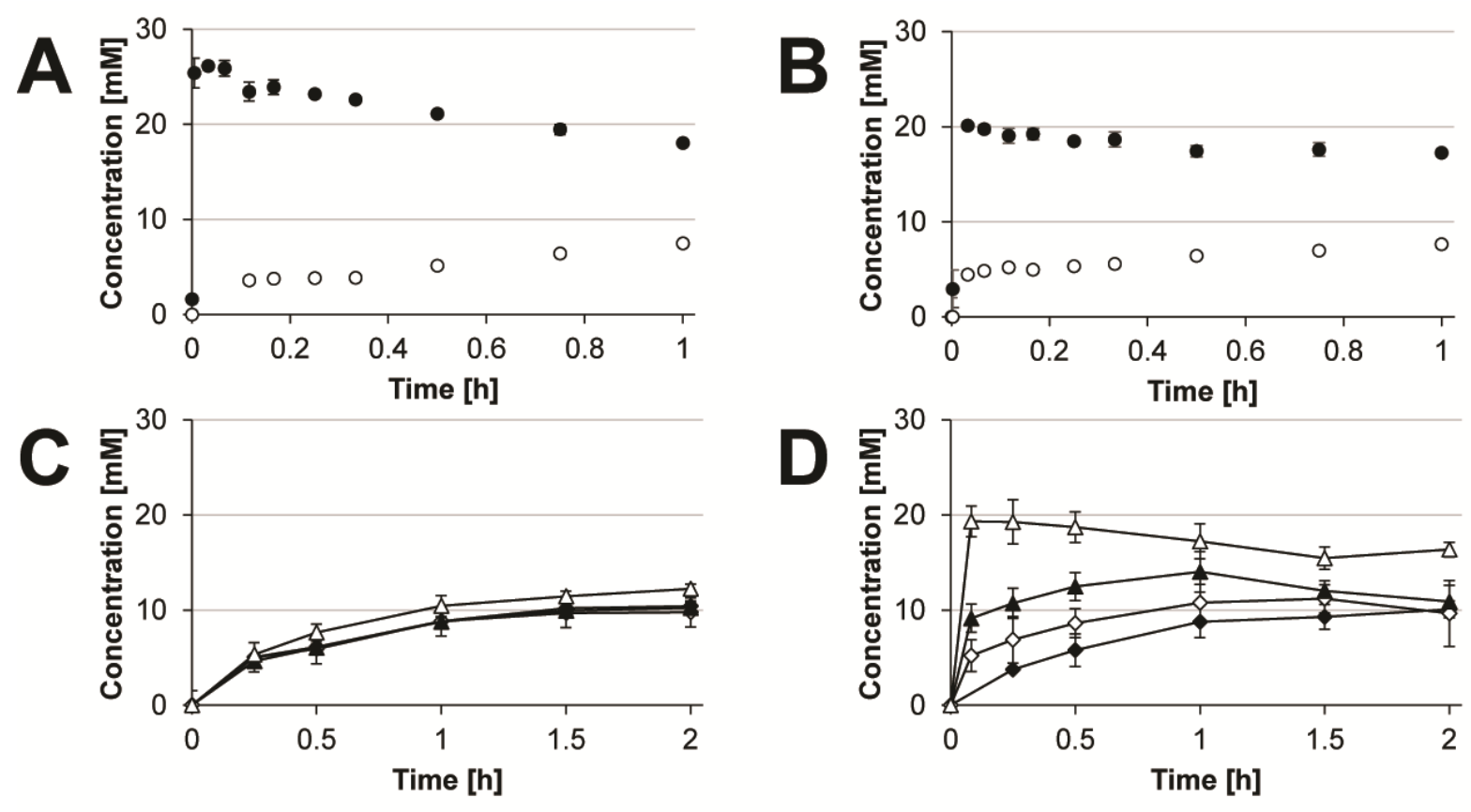

Figure 3. Cell-free conversion from pyruvate to 2,3-BD is fast but redox limited. Twenty-five microliter batch reactions at $37^{\circ} \mathrm{C}$ with $50 \mathrm{mM}$ pyruvate and $1 \mathrm{mM} \mathrm{NAD+}$ were prepared in different tubes for each time point and sampled for 2,3-BD and acetoin production. (A) meso-2,3-butanediol pathway enzymes. m2,3-BD (open circles), acetoin (filled circles). (B) R,R-2,3-BD pathway enzymes. R,R2,3-BD (open circles), acetoin (filled circles). (C,D) Cell-free conversion of $50 \mathrm{mM}$ pyruvate to m2,3-BD with different starting concentrations of NAD+ (C) or NADH (D): 1 $\mathrm{mM}$ (filled diamonds), $5 \mathrm{mM}$ (open diamonds), $10 \mathrm{mM}$ (filled triangles), and $25 \mathrm{mM}$ (open triangles). In $C$ and $D$, only 2,3-BD concentration is shown. Values represent averages from three independent experiments and error bars represent 1 standard deviation (s.d.).

Since one $\mathrm{NADH}$ is required to convert acetoin to 2,3-BD, the accumulation of acetoin suggested that the availability of reduced cofactor was limiting the reaction. Only $1 \mathrm{mM}$ of NAD+ was added to the reactions, but since the extract is not dialyzed, it may contain either NADH or alternative pathways, such as active glutamate metabolism, to regenerate NADH to produce the observed 2,3-BD. Previously, CFPS reactions carried out using a similar physicochemical environment have shown the ability activate glycolysis, the TCA cycle, and membrane dependent respiration from inverted 
membrane vesicles to regenerate NADH (Jewett et al., 2008). To test if NADH was limiting, we carried out CFME batch reactions with additional NAD+ (1-25 mM) and NADH (1-25 mM). Here, we monitored m2,3-BD production over time. Figure 3, panels $C$ and $D$, show the course of the reaction when we added NAD+ and NADH at increasing initial concentrations. Increasing NAD+ only appeared to slightly, if at all, speed the progress of the reaction. In contrast, adding NADH resulted in almost complete conversion of pyruvate to 2,3-BD within one minute. Less acetoin, succinate, and acetate were also produced in reactions supplemented with NADH (Supplementary Figure 4). Interestingly, as the reaction progressed, it appears that somehow an equilibrium for the last step of the pathway is being established.

\subsection{Cell-free bioconversions of 2,3-BD from glucose}

We next investigated the possibility of activating native glycolytic enzymes in the crude extract to convert glucose to pyruvate, and subsequent production of 2,3-BD. Since our initial experiments showed that $\mathrm{NADH}$ drives the completion of the pathway, we hypothesized that glucose could provide both starting material for the heterologous pathway in the form of pyruvate and reduced cofactor to drive the reaction forward by glycolysis. Glycolysis has been previously demonstrated to be active in E. coli extracts to fuel CFPS (Calhoun and Swartz, 2005). That study found $10 \mathrm{mM}$ potassium phosphate and $1 \mathrm{mM}$ ATP necessary to activate glycolysis in a similar E. coli lysate, so we added these components to our standard reaction mixture to test whether or not glucose could fuel 2,3-BD synthesis. We carried out cell-free bioconversions for 2,3-BD with lysates from both synthetic pathways as above, except pyruvate was now replaced 
with glucose as a substrate, and $10 \mathrm{mM}$ phosphate and $1 \mathrm{mM}$ ATP were also added. Strikingly, we observed high conversion of glucose to 2,3-BD. During m2,3-BD production, $200 \mathrm{mM}$ glucose was completely consumed and converted to $159 \pm 1 \mathrm{mM}$ $\mathrm{m} 2,3-\mathrm{BD}$ in $3.75 \mathrm{~h}$ with a linear rate of $46.3 \pm 0.6 \mathrm{mM} \cdot \mathrm{h}^{-1}$ or $4.2 \mathrm{~g} \cdot \mathrm{L} \cdot \mathrm{h}^{-1}$ (Figure $4 \mathrm{~A}$ ). This

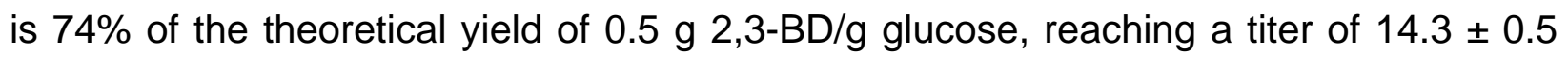
$\mathrm{g} / \mathrm{L}$. The $\mathrm{pH}$ of the reaction drops rapidly and holds at $\sim 6.1-6.3$. Unlike the reactions directed from pyruvate, in this case we did not observe the accumulation of acetoin (Figure 4A).
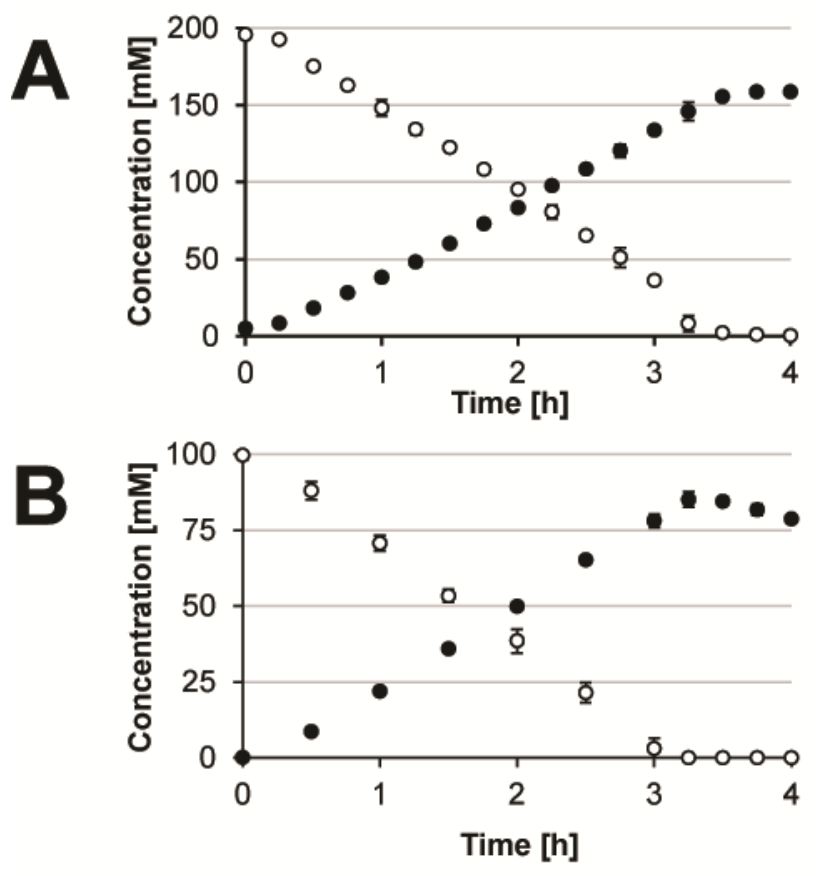

Figure 4. Conversion of 2,3-BD from glucose provides benefits for pathway operation and high yields. Twenty-five microliter batch reactions at $37{ }^{\circ} \mathrm{C}$ were prepared in different tubes for each time point and sampled for glucose, 2,3-BD and acetoin production. (A) m2,3-BD pathway enzymes. Glucose (open circles), m2,3-BD (closed circles). (B) R,R-2,3-BD pathway enzymes. glucose (open circles), R,R-2,3-BD (closed circles). In both cases, little to no acetoin was produced (Supplementary Figure 6). Specific reaction conditions shown in Table 3, noting that R,R-2,3-BD pathway required $200 \mathrm{mM}$ HEPES buffer $\mathrm{pH} 8.2$ as described in the text. Values represent averages $(n \geq 3)$ and error bars represent 1 s.d. 
While $\mathrm{m} 2,3-\mathrm{BD}$ and $\mathrm{R}, \mathrm{R}-2,3-\mathrm{BD}$ synthesis were similar when using pyruvate as an initial substrate, we observed differences when using glucose as a substrate. Conversion of glucose to R,R-2,3-BD was very slow and ended rapidly at $\sim 3$ hours (Supplementary Figure 5). For unknown reasons, we observed that the $\mathrm{pH}$ did not hold above 6 for the R,R-2,3-BD-producing extract (as in the m2,3-BD pathway) but continued to decrease to a final value of 5.5 at 3 hours. $\mathrm{pH}$ decreases were also a problem when consuming glucose for other CFPS systems and buffer strength was increased to counteract this effect (Calhoun and Swartz, 2005). In attempts to stabilize $\mathrm{pH}$ in the R,R-2,3-BD pathway in order to assess if $\mathrm{pH}$ was responsible for decreased enzyme activity, we screened several buffers. We found that $200 \mathrm{mM}$ HEPES buffer at pH 8.2 enabled production of $R, R-2,3-B D$ at a linear rate of $28.1 \pm 0.3 \mathrm{mM} R, \mathrm{R}-2,3-\mathrm{BD}$ per hour or 2.5 $g \cdot L \cdot h^{-1}$ (Figure 4B). Interestingly, the addition of buffer did not benefit the m2,3-BD pathway. Although we do not fully understand why the two pathways function differently, all subsequent experiments were carried out using only the m2,3-BD pathway because the rate of conversion was higher and $\mathrm{pH}$ more stable.

To study m2,3-BD bioconversions with finer resolution, we next quantified small molecule organic acid concentrations at selected time points in batch reactions using HPLC (Supplementary Figure 6). Not only did the cell-free reactions not produce quantifiable levels of acetoin, but they consumed acetate (which is present as a result of salts used to mimic the physicochemical environment) and produced ethanol. These data suggest that there is excess reducing power in the cell-free reactions as compared 
to in cells. In our cell-free system, we did not observe measureable formate, pyruvate, or succinate when glucose is used as the substrate.

One of the exciting implications of the m2,3-BD synthesis data is that NADH must be

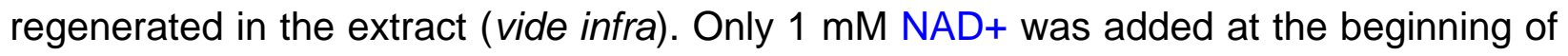
the reaction, while one reducing equivalent is required for each mole of 2,3-BD generated. Yet, $159 \pm 1 \mathrm{mM} \mathrm{m} 2,3-\mathrm{BD}$ was produced in a 3 hour batch reaction, proceeding linearly until all of the glucose was consumed. Thus, our data suggests that production of m2,3-BD was proportional to the amount of glucose supplied.

For completeness, we also performed shake-flask cultivation time course experiments with the BL21 strains harboring the 2,3-BD production pathway plasmids used to produce extract for this study (Supplementary Figure 7). We observed about 5mM $\mathrm{m} 2,3-\mathrm{BD}$ (or $0.5 \mathrm{~g} / \mathrm{L}$ ) after 24 hours of induction from the E. coli strain harboring alsS, alsD, and budC genes (Supplementary Figure $7 C$ ). Our time course analysis shows production of up to $20 \mathrm{mM}$ m2,3-BD during the first 12 hours; however, acetoin is the favored product at 24 hours after induction. As shown in Supplementary Figure 7D, we observed little to no production of 2,3-BD from the $E$. coli strain harboring ilvBN, aldB, and butB genes. These data, which were carried out in a wild type E. coli BL21 strain, are consistent with the work of Nielsen et al. (Biotech. J, 2010), who used the same set of enzyme genes in E. coli as we did. Nielsen et al. required a strain with several gene knockouts to observe measureable 2,3-BD. We believe that the context of both strain choice and plasmid (i.e., balance of pathway enzymes) impacts 2,3-BD production, as 
has been explored elsewhere (Xu et al., 2014). Since the goal of this study was to demonstrate a new approach for CFME, and not design an engineered strain for best fermentative production of 2,3-BD in cells, we next looked at the potential to increase the scale of our cell-free reactions.

Recent attempts in crude extract based cell-free protein synthesis, have demonstrated linear scalability for commercial protein yields and rates from the microliter to the $5 \mathrm{~L}$ scale for aglycosylated antibodies (Yin et al. MAbs 2012) and microliter to the $100 \mathrm{~L}$ scale for cytokines (Zawada et al., Biotechnol. Bioeng. 2011), an expansion factor of $10^{6}$. We were curious as to how the CFME reactions would perform at increased scale. Thus, the reaction volume of 2,3-BD CFME reactions was scaled from 15 to $250 \mu \mathrm{L}$ in both microcentrifuge tubes and a flat-bottom 24-well plate (Supplementary Figure 8). By increasing the reaction volume from 15 to $250 \mu \mathrm{L}$ in the microcentrifuge tube, the efficiency of 2,3-BD production decreased, whereas the same reactions in the flatbottom 24-well plate did not decrease 2,3-BD concentration (Supplementary Figure 8). Our results are consistent with those of Voloshin and Swartz (2005) and Hong et al., (2015) who reported these phenomena previously, specifically that the surface area to volume ratio is important for cell-free reaction activity (Hong et al., 2015; Voloshin and Swartz, 2005). In summary, our results indicate that CFME is scalable when accounting for surface-area-to-volume effects, just as observed for crude extract based cell-free protein synthesis.

\subsection{Fed-batch cell-free bioconversions}


Since our data suggested glucose depletion as a source of reaction termination (Figure $4 A)$, we then performed fed-batch experiments to determine if replenishing glucose could extend the duration of 2,3-BD biosynthesis. We observed that the reaction duration could indeed be extended by glucose supplementation in fed-batch operation. An additional $200 \mathrm{mM}$ glucose added every three hours resulted in accumulation of 33 $\mathrm{g} / \mathrm{L} \mathrm{m2,3-BD}$ by 12 hours (Figure $5 \mathrm{~A}$ ). Over the course of the reaction, the total volume of the reaction was increased $\sim 20 \%$ to $29.5 \mu \mathrm{L}$ and the rate began to decrease. Possible causes of reaction decrease included dilution, product inhibition, and deactivation of enzymes over time, which we subsequently attempted to understand. To do so, we first measured the initial rate of m2,3-BD generation, defined here as the average linear rate between 15 and 90 minutes after glucose addition, when varying initial product concentration (Figure 5B), extract concentration (Figure 5C), or introducing a delay to substrate addition to isolate each of these factors. In Figure 5B, concentrations of $\mathrm{m} 2,3-\mathrm{BD}$ less than $1 \mathrm{M}$ were added with the original reaction components. The initial rate of $2,3-B D$ production decreased linearly at $30 \mathrm{mM} \cdot \mathrm{h}^{-1} \cdot[\mathrm{M}$ 2,3-BD] $]^{-1}$ and was more than halved before $1 \mathrm{M} \mathrm{m} 2,3-\mathrm{BD}$ was reached, indicating product inhibition. Reducing product inhibition could be a step to improve yields moving forward. We also found that the initial reaction rate was linearly dependent on extract concentration, with the most concentrated extract producing the highest rate (Figure 5C). Unfortunately, increasing the final reaction extract concentration beyond $\sim 40 \mathrm{mg} / \mathrm{mL}$ was not feasible due to volume restrictions. Figure 5D shows that the half-life of the extract at the standard $13 \mathrm{mg} / \mathrm{mL}$ concentration was approximately 18 hours, meaning that some of the enzymes in the extract that participate in the conversion of glucose to 
2,3-BD or energy and cofactor regeneration lose activity over time. Two ways to improve the extract lifetime would be to find ways of decreasing deactivation rate such as with protease inhibitors or perhaps improvements to allow operation at a lower temperature.
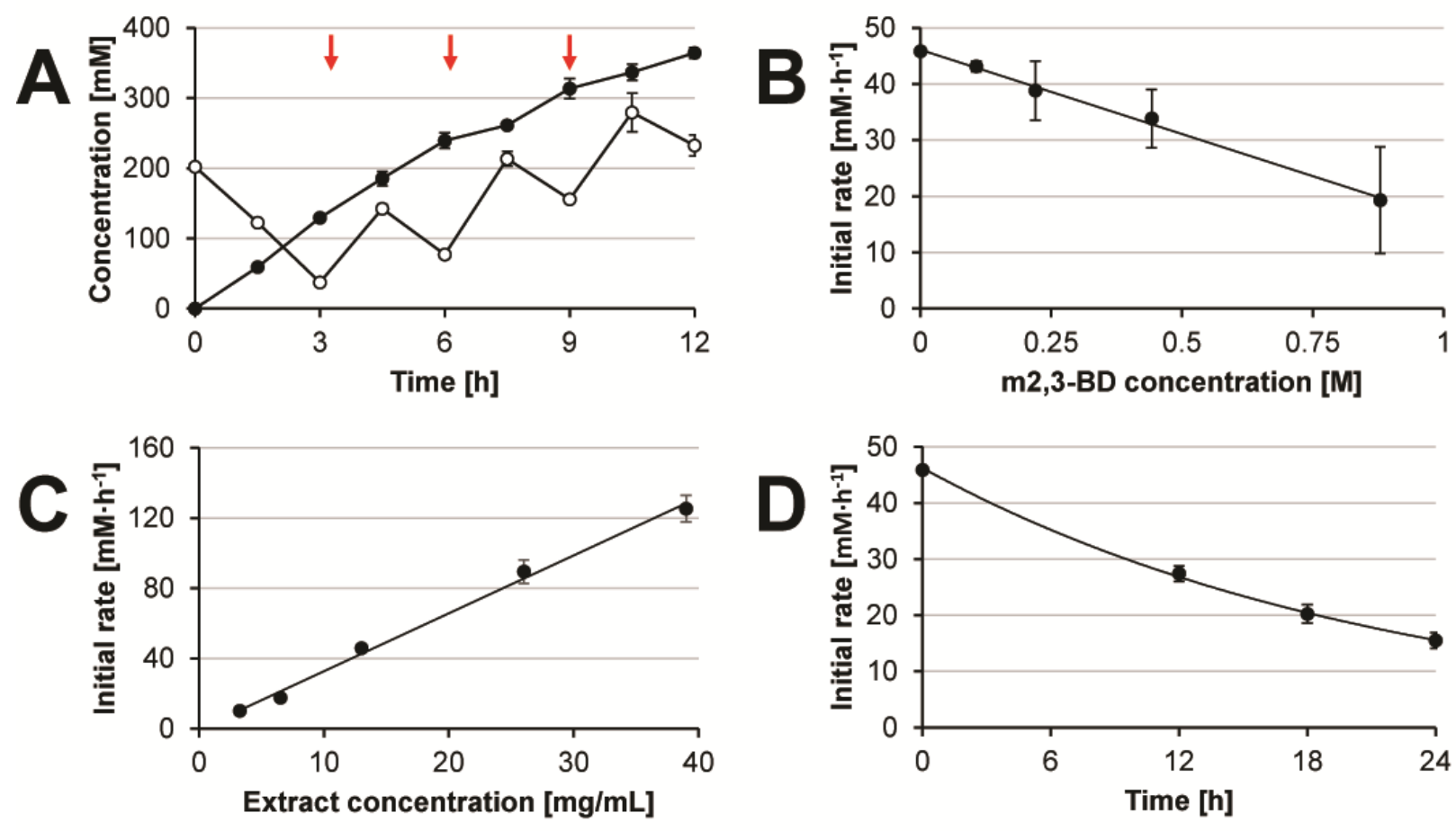

Figure 5. Fed-batch operation extends reaction duration and increases overall $\mathbf{g} / \mathbf{L}$ titers. (A) Twenty-five microliter fed-batch reactions at $37^{\circ} \mathrm{C}$ were prepared in different tubes for each time point and sampled for glucose (open circles), 2,3-BD (closed circles) and acetoin production (end value $15 \pm 1 \mathrm{mM}$, not shown). Replenishing glucose $(1.5 \mu \mathrm{L} 600 \mathrm{~g} / \mathrm{L}$ every three hours at red arrows) during CFME reactions prolongs duration and increases overall $m 2,3-B D$ titers. (B-D) Initial rates were calculated as described in the Methods Section 2.8. (B) Increasing concentrations of m2,3-BD were added at the start of twenty-five microliter batch CFME reactions. m2,3$\mathrm{BD}$ was found to inhibit the initial rate of conversion of glucose to m2,3-BD synthesis (i.e., product inhibition). (C) Batch reactions were performed with increasing concentrations of pathway-enriched extract. The m2,3-BD conversion rate is linearly dependent on amount of lysate added to the reaction. (D) Pre-incubation experiments assess lysate activity not in the presence of substrates. In these experiments, the reaction components described in Table 3 except glucose were pre-incubated for 0,12 , 18 , and $24 \mathrm{~h}$ prior to the initiation of the CFME reaction to produce m2,3-BD with glucose. A small amount of m2,3-BD, approximately 6,10 , and $12 \mathrm{mM}$ respectively, accumulated during the 12, 18, and 24 hour incubations. Values represent averages $(n \geq 2)$ and error bars represent 1 s.d. 
Given the high initial rates observed when increasing extract concentration (Figure 5C), we carried out an additional set of fed-batch experiments with prolonged duration and $39 \pm 1 \mathrm{mg}$ total protein/mL ( $3 x$ that shown in Figure $5 \mathrm{~A})$. These experiments are shown in Figure 6. Glucose was consumed more quickly in this reaction, so the feeding strategy was adjusted to supply more glucose with minimal dilution of the reaction. A maximum titer of $82 \pm 8 \mathrm{~g} \cdot \mathrm{L}^{-1}$ was reached with a theoretical yield of $64 \%$ (Figure 6 ). Consistent with this calculation, some byproducts were observed (Supplementary Figure 9). For example, after 30 hours we produced $11 \pm 3 \mathrm{mM}$ acetoin, consumed acetate, and produced lactate and ethanol. These data suggest that there is excess reducing power in the cell-free reactions, which makes sense since 2 equivalents of $\mathrm{NADH}$ are produced from every glucose molecule but only one equivalent is consumed in the pathway towards $2,3-\mathrm{BD}$ synthesis. The average productivity from the data in Figure 6 , was $2.7 \mathrm{~g} \cdot \mathrm{L} \cdot \mathrm{h}^{-1}$, with a peak productivity of $11.3 \mathrm{~g} \cdot \mathrm{L}^{-1} \cdot \mathrm{h}^{-1}$. The volumetric productivity slowed down over time, likely due to inhibitory effects of the product and deactivation of the enzymes over time (Figure 5, panels B and D). 


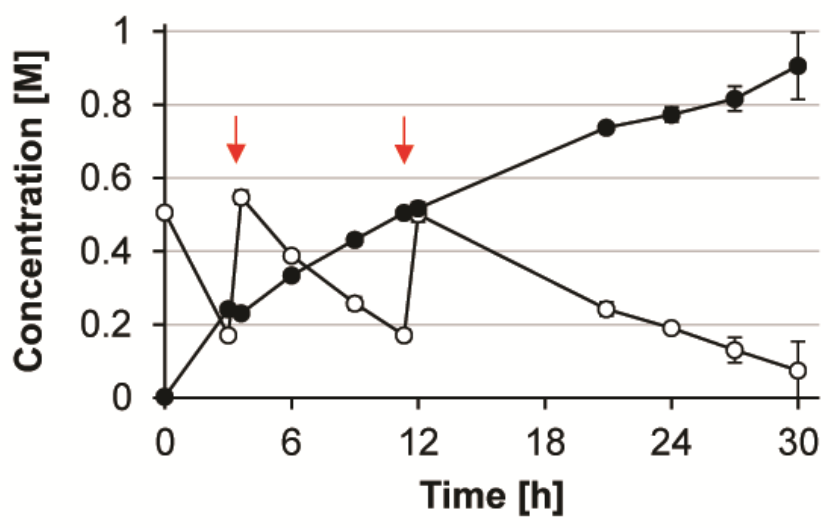

Figure 6. m2,3-BD fed-batch production titers are increased by increasing catalyst (i.e. lysate) concentrations. Twenty-five microliter fed-batch reactions with $39 \mathrm{mg}$ total protein $/ \mathrm{mL}$ were prepared in different tubes for each time point and sampled for glucose (open circles), 2,3-BD (closed circles) and acetoin production (end value $11 \pm 3 \mathrm{mM}$, Supplement Figure 9). Replenishing glucose during the CFME reaction $(2.8 \mu \mathrm{L} 800 \mathrm{~g} / \mathrm{L}$ glucose at 3 and $12 \mathrm{~h}$ to maintain glucose concentrations at or under $500 \mathrm{mM}$ ) prolongs duration and increases overall m2,3-BD titers. Values represent averages $(n \geq 3)$ and error bars represent 1 s.d.

To see whether the extract concentration effect was due to increased concentration of the exogenous enzymes or native components of the extract, endpoint titers (Figure 7A) and initial productivities (Figure 7B) were taken for mixtures of the extract enriched with pathway enzymes and extract derived from BL21(DE3) lacking such enzymes (data used to calculate productivities is shown in Supplementary Figure 10). While decreasing the portion of pathway-enriched extract does decrease the rate and titer, the effect is not proportional to heterologous enzyme concentration. For example, decreasing the concentration of heterologous pathway enzymes four-fold only results in a $25 \%$ decrease in initial rate. Importantly, these results suggest that some other component of the extract is limiting, such as one of the glycolytic enzymes, or a component of the crude lysate that may be involved in cofactor regeneration. 

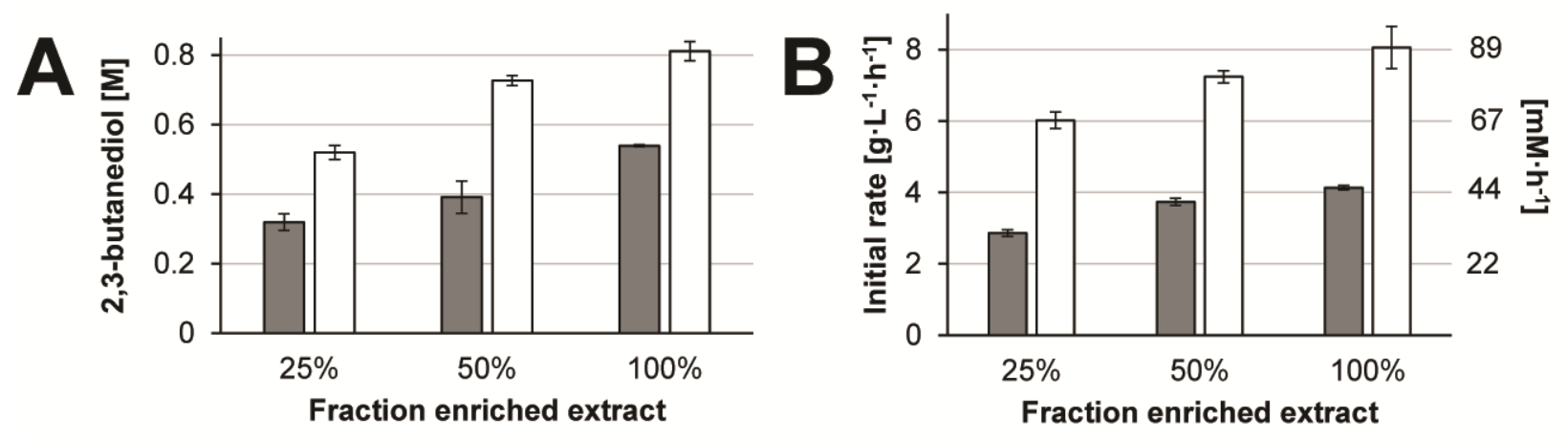

Figure 7. Dilution of selectively enriched lysates with extract generated without pathway enzymes suggests a native component in glycolysis or cofactor regeneration is limiting overall performance rate. Extract containing the heterologous m2,3-BD pathway enzymes was diluted with extract from standard BL21(DE3) cells lacking such enzymes to evaluate the titer at 30h (A) and initial rate (B) of $\mathrm{m} 2,3-\mathrm{BD}$ production in batch CFME reactions. The fraction of pathway-enriched lysate $(25 \%, 50 \%$, or $100 \%)$ is shown on the X-axis. The total protein concentration was the standard concentration (13 mg total protein $/ \mathrm{mL}$, grey) or 2 times this value (26 $\mathrm{mg} / \mathrm{mL}$, white). Values represent averages $(n \geq 3)$ and error bars represent 1 s.d.

\section{Conclusion}

We set out to show that activation of native pathways in crude cell extracts from $E$. coli could fuel very active heterologous metabolic pathways with high co-factor regeneration. As intended, we showed the activation of a 13-step pathway, comprising 10 glycolytic enzymes and 3 overexpressed enzymes that in sum convert glucose to 2,3-BD. Specifically, we engineered a single strain of E. coli to express three pathway enzymes necessary to make 2,3-BD. Following lysis of the source strain, we observed $74 \%$ molar conversion of glucose to $2,3-\mathrm{BDO}$ in $3.75 \mathrm{~h}$ batch cell-free reaction with linear productivity of $4.2 \mathrm{~g} / \mathrm{L} / \mathrm{h}$, stopping only because the catalyst ran out of glucose. In fed-batch reactions with concentrated extracts (Figure 6), we observed 64\% conversion yields, high titers $\left(82 \pm 8 \mathrm{~g} \cdot \mathrm{L}^{-1}\right)$, and high productivities $\left(\sim 2.7 \mathrm{~g} \cdot \mathrm{L} \cdot \mathrm{h}^{-1}\right.$, with a peak productivity of $\left.\sim 11.3 \mathrm{~g} \cdot \mathrm{L}^{-1} \cdot \mathrm{h}^{-1}\right)$. Surprisingly, these yields and productivities occurred 
with no strain optimization. Most notably, we achieved high co-factor regeneration by leveraging native metabolism in the lysate. In order to produce $900 \pm 90 \mathrm{mM} \mathrm{m2,3-BD \text {, }}$ approximately 900 turnover events would need to occur. This far exceeds typical turnover numbers in purified enzyme CFME systems, which are 5-10 (Dudley et al., 2015), noting however that some efforts have demonstrated high cofactor turnover in reconstituted systems. For example, Welch and Scopes (1985) reconstituted a system of purified glycolytic enzymes capable of converting $1 \mathrm{M}$ glucose to ethanol in 8 hours with nearly $100 \%$ molar yield. Total turnover number in our system also exceeded that from the synthesis of dihydroxyacetone phosphate (DHAP) in crude E. coli lysates (Bujara et al., 2010). It appears one previous system that used a yeast cell-free lysate system to produce ethanol from glucose has achieved a higher cofactor turnover (>1500) (Khattak et al., 2014). However, our work is unique in its use of a heterologous pathway rather than an endogenous pathway.

By demonstrating that highly active, cofactor regenerating, low-cost lysates are capable of efficient heterologous metabolic conversion, we have provided a new approach to address several key challenges for CFME (e.g., low volumetric productivities (g/L/h), limited cofactor and energy regeneration capabilities, high system catalyst costs (especially protein purification for purified synthetic enzymatic pathways), etc. (Dudley et al., 2015)). Thus, our efforts open the way to a generalized strategy for pathway optimization and debugging in vitro in a system that mimics the cytoplasm in easily prepared lysates. 
Looking forward, we aim to expand our efforts in CFME to create a more general cellfree framework for rapid biosynthetic pathway prototyping and debugging and to make CFME more economical. To address the latter opportunity, we anticipate that the lower the extract concentration used and the longer it can be used, the more economical the process will be. Opportunities to further improve the system include comprehensively identifying and removing byproduct pathways, identifying limiting native enzymes from the lysate, reducing product inhibition, prolonging lysate stability, and developing strategies for continuous feeding. Furthermore, we plan to determine what features of our platform can be generalized to other, more challenging, product pathways. Finally, we seek to increase understanding of the metabolism of cell-free lysates. For example, we are currently developing methods to prepare cell-free reaction samples for mass spectrophotometry and other more sensitive techniques to obtain the identity of reaction byproducts and fluxes through central metabolism. In elegant and pioneering work, Panke and colleagues have previously used such an approach to map and optimize pathways (Bujara et al., 2011). Given our success at making 2,3-BD at high titers, yields and productivities with no strain modifications or plasmid optimization, we also believe that our work raises the intriguing possibility for using cell-free biomanufacturing in crude extract for the production of high value, hybrid, and toxic molecules (Dudley et al., 2015; Swartz, 2012). We therefore anticipate that the approach outlined here could enable new frontiers for rapidly generating and evaluating new enzymes and metabolic pathways in well-defined experimental conditions and biomanufacturing when conversion yields (g product/L), productivities (g product/L/h), or cellular toxicity limit commercial feasibility of whole-cell fermentation. 


\section{Acknowledgements}

Research for this paper was conducted with Government support under contract FA9550-11-C-0028 and awarded by the Department of Defense, Air Force Office of

Scientific Research, National Defense Science and Engineering Graduate (NDSEG) Fellowship, 32 CFR 168a (to JEK). Additional support was from the David and Lucille Packard Foundation (to MCJ) and the National Science Foundation NSF (MCB0943383). We thank Nicholas Thornburg and the Notestein lab for use and assistance with their GC-MS.

\section{References}

Adrio, J., Demain, A., 2014. Microbial Enzymes: Tools for Biotechnological Processes. Biomolecules. 4, 117-139.

Ajikumar, P. K., Xiao, W. H., Tyo, K. E., Wang, Y., Simeon, F., Leonard, E., Mucha, O., Phon, T. H., Pfeifer, B., Stephanopoulos, G., 2010. Isoprenoid pathway optimization for Taxol precursor overproduction in Escherichia coli. Science. 330, 70-4.

Alper, H., Stephanopoulos, G., 2007. Global transcription machinery engineering: a new approach for improving cellular phenotype. Metab Eng. 9, 258-67.

Anderson, J. C., Dueber, J. E., Leguia, M., Wu, G. C., Goler, J. A., Arkin, A. P., Keasling, J. D., 2010. BglBricks: A flexible standard for biological part assembly. Journal of Biological Engineering. 4, 1-1.

Billerbeck, S., Harle, J., Panke, S., 2013. The good of two worlds: increasing complexity in cell-free systems. Curr. Opin. Biotechnol. 24, 1037-1043.

Blazeck, J., Liu, L., Redden, H., Alper, H., 2011. Tuning gene expression in Yarrowia lipolytica by a hybrid promoter approach. Appl Environ Microbiol. 77, 7905-14.

Bond-Watts, B. B., Bellerose, R. J., Chang, M. C. Y., 2011. Enzyme mechanism as a kinetic control element for designing synthetic biofuel pathways. Nat. Chem. Biol. 7, $222-227$.

Bujara, M., Schumperli, M., Billerbeck, S., Heinemann, M., Panke, S., 2010. Exploiting cell-free systems: Implementation and debugging of a system of biotransformations. Biotechnol Bioeng. 106, 376-89.

Bujara, M., Schumperli, M., Pellaux, R., Heinemann, M., Panke, S., 2011. Optimization of a blueprint for in vitro glycolysis by metabolic real-time analysis. Nat Chem Biol. 7, 271-7.

Burgard, A. P., Van Dien, S. J., Burk, M., Methods and organisms for the growthcoupled production of 1,4-butanediol. Google Patents, 2011. 
Calhoun, K. A., Swartz, J. R., 2005. Energizing cell-free protein synthesis with glucose metabolism. Biotechnol. Bioeng. 90, 606-613.

Carlson, E. D., Gan, R., Hodgman, C. E., Jewett, M. C., 2012. Cell-free protein synthesis: Applications come of age. Biotechnol. Adv. 30, 1185-1194.

Caschera, F., Noireaux, V., 2014. Integration of biological parts toward the synthesis of a minimal cell. Curr. Opin. Chem. Biol. 22, 85-91.

Caschera, F., Noireaux, V., 2015. A cost-effective polyphosphate-based metabolism fuels an all E. coli cell-free expression system. Metab Eng. 27, 29-37.

Chappell, J., Takahashi, M. K., Lucks, J. B., 2015. Creating small transcription activating RNAs. Nat Chem Biol. 11, 214-20.

Du, J., Yuan, Y., Si, T., Lian, J., Zhao, H., 2012. Customized optimization of metabolic pathways by combinatorial transcriptional engineering. Nucleic Acids Res. 40, e142.

Dudley, Q. M., Karim, A. S., Jewett, M. C., 2015. Cell-free metabolic engineering: biomanufacturing beyond the cell. Biotechnol J. 10, 69-82.

Gibson, D. G., Young, L., Chuang, R.-Y., Venter, J. C., Hutchison, C. A., Smith, H. O., 2009. Enzymatic assembly of DNA molecules up to several hundred kilobases. Nat Meth. 6, 343-345.

Gronenberg, L. S., Marcheschi, R. J., Liao, J. C., 2013. Next generation biofuel engineering in prokaryotes. Curr. Opin. Chem. Biol. 17, 462-471.

Guterl, J. K., Garbe, D., Carsten, J., Steffler, F., Sommer, B., Reisse, S., Philipp, A., Haack, M., Ruhmann, B., Koltermann, A., Kettling, U., Bruck, T., Sieber, V., 2012. Cell-Free Metabolic Engineering: Production of Chemicals by Minimized Reaction Cascades. ChemSusChem. 5, 2165-2172.

Hodgman, C. E., Jewett, M. C., 2012. Cell-free synthetic biology: Thinking outside the cell. Metab. Eng. 14, 261-269.

Hong, S. H., Kwon, Y.-C., Martin, R. W., Des Soye, B. J., de Paz, A. M., Swonger, K. N., Ntai, I., Kelleher, N. L., Jewett, M. C., 2015. Improving Cell-Free Protein Synthesis through Genome Engineering of Escherichia coli Lacking Release Factor 1. ChemBioChem. 16, 844-853.

Jewett, M. C., Calhoun, K. A., Voloshin, A., Wuu, J. J., Swartz, J. R., 2008. An integrated cell-free metabolic platform for protein production and synthetic biology. Mol. Syst. Biol. 4.

Jewett, M. C., Swartz, J. R., 2004. Mimicking the Escherichia coli cytoplasmic environment activates long-lived and efficient cell-free protein synthesis. Biotechnol. Bioeng. 86, 19-26.

Ji, X. J., Huang, H., Ouyang, P. K., 2011. Microbial 2,3-butanediol production: A stateof-the-art review. Biotechnol. Adv. 29, 351-364.

Ji, X. J., Liu, L. G., Shen, M. Q., Nie, Z. K., Tong, Y. J., Huang, H., 2014. Constructing a synthetic metabolic pathway in Escherichia coli to produce the enantiomerically pure $(R, R)-2,3-$ butanediol. Biotechnol Bioeng.

Karig, D. K., lyer, S., Simpson, M. L., Doktycz, M. J., 2012. Expression optimization and synthetic gene networks in cell-free systems. Nucleic Acids Res. 40, 3763-74.

Kern, A., Tilley, E., Hunter, I. S., Legiša, M., Glieder, A., 2007. Engineering primary metabolic pathways of industrial micro-organisms. Journal of Biotechnology. 129, 6-29. 
Khattak, W. A., Ul-Islam, M., Ullah, M. W., Yu, B., Khan, S., Park, J. K., 2014. Yeast cell-free enzyme system for bio-ethanol production at elevated temperatures. Process Biochem. 49, 357-364.

Kopke, M., Mihalcea, C., Liew, F., Tizard, J. H., Ali, M. S., Conolly, J. J., Al-Sinawi, B., Simpson, S. D., 2011. 2,3-butanediol production by acetogenic bacteria, an alternative route to chemical synthesis, using industrial waste gas. Appl Environ Microbiol. 77, 5467-75.

Kwok, R., 2010. Five hard truths for synthetic biology. Nature. 463, 288-90.

Lee, J. W., Na, D., Park, J. M., Lee, J., Choi, S., Lee, S. Y., 2012. Systems metabolic engineering of microorganisms for natural and non-natural chemicals. Nat. Chem. Biol. 8, 536-546.

Li, S., Yang, X., Yang, S., Zhu, M., Wang, X., 2012. Technology prospecting on enzymes: application, marketing, and engineering. Computational and Structural Biotechnology Journal. 2, 1-11.

Nakamura, C. E., Whited, G. M., 2003. Metabolic engineering for the microbial production of 1,3-propanediol. Curr. Opin. Biotechnol. 14, 454-459.

Nielsen, D. R., Yoon, S. H., Yuan, C. J., Prather, K. L., 2010. Metabolic engineering of acetoin and meso-2, 3-butanediol biosynthesis in E. coli. Biotechnol J. 5, 274-84.

Nielsen, J., Fussenegger, M., Keasling, J., Lee, S. Y., Liao, J. C., Prather, K., Palsson, B., 2014. Engineering synergy in biotechnology. Nat Chem Biol. 10, 319-322.

Paddon, C. J., Westfall, P. J., Pitera, D. J., Benjamin, K., Fisher, K., McPhee, D., Leavell, M. D., Tai, A., Main, A., Eng, D., Polichuk, D. R., Teoh, K. H., Reed, D. W., Treynor, T., Lenihan, J., Fleck, M., Bajad, S., Dang, G., Dengrove, D., Diola, D., Dorin, G., Ellens, K. W., Fickes, S., Galazzo, J., Gaucher, S. P., Geistlinger, T., Henry, R., Hepp, M., Horning, T., Iqbal, T., Jiang, H., Kizer, L., Lieu, B., Melis, D., Moss, N., Regentin, R., Secrest, S., Tsuruta, H., Vazquez, R., Westblade, L. F., Xu, L., Yu, M., Zhang, Y., Zhao, L., Lievense, J., Covello, P. S., Keasling, J. D., Reiling, K. K., Renninger, N. S., Newman, J. D., 2013. High-level semisynthetic production of the potent antimalarial artemisinin. Nature. 496, 528-+.

Rollin, J. A., Tam, T. K., Zhang, Y. H. P., 2013. New biotechnology paradigm: cell-free biosystems for biomanufacturing. Green Chem. 15, 1708-1719.

Salis, H. M., 2011. Chapter two - The Ribosome Binding Site Calculator. In: Christopher, V., (Ed.), Methods in Enzymology. vol. Volume 498. Academic Press, pp. 19-42.

Sanchez, S., Demain, A. L., 2011. Enzymes and Bioconversions of Industrial, Pharmaceutical, and Biotechnological Significance. Org. Process Res. Dev. 15, 224-230.

Shin, J., Noireaux, V., 2012. An E. coli cell-free expression toolbox: application to synthetic gene circuits and artificial cells. ACS Synth Biol. 1, 29-41.

Sun, Z. Z., Yeung, E., Hayes, C. A., Noireaux, V., Murray, R. M., 2014. Linear DNA for Rapid Prototyping of Synthetic Biological Circuits in an Escherichia coli Based TX-TL Cell-Free System. ACS Synth. Biol. 3, 387-397.

Swartz, J. R., 2012. Transforming Biochemical Engineering with Cell-Free Biology. Aiche J. 58, 5-13.

Takahashi, M. K., Chappell, J., Hayes, C. A., Sun, Z. Z., Kim, J., Singhal, V., Spring, K. J., Al-Khabouri, S., Fall, C. P., Noireaux, V., Murray, R. M., Lucks, J. B., 2014. 
Rapidly Characterizing the Fast Dynamics of RNA Genetic Circuitry with CellFree Transcription-Translation (TX-TL) Systems. ACS Synth Biol.

Voloshin, A. M., Swartz, J. R., 2005. Efficient and scalable method for scaling up cell free protein synthesis in batch mode. Biotechnol. Bioeng. 91, 516-521.

Welch, P., Scopes, R. K., 1985. Studies on Cell-Free Metabolism - Ethanol-Production by a Yeast Glycolytic System Reconstituted from Purified Enzymes. Journal of Biotechnology. 2, 257-273.

Xu, Y., Chu, H., Gao, C., Tao, F., Zhou, Z., Li, K., Li, L., Ma, C., Xu, P., 2014. Systematic metabolic engineering of Escherichia coli for high-yield production of fuel bio-chemical 2,3-butanediol. Metab Eng. 23, 22-33.

Yan, Y., Lee, C. C., Liao, J. C., 2009. Enantioselective synthesis of pure (R,R)-2,3butanediol in Escherichia coli with stereospecific secondary alcohol dehydrogenases. Org Biomol Chem. 7, 3914-7.

You, C., Zhang, Y. H. P., 2013. Cell-Free Biosystems for Biomanufacturing. In: Zhong, J. J., (Ed.), Future Trends in Biotechnology. vol. 131. Springer-Verlag Berlin, Berlin, pp. 89-119.

\section{PROPOSED FIGURE SIZES}

Figure 1 - one and a half columns

Figure 2 - one column

Figure 3 - two column

Figure 4 - one column

Figure 5 - two column

Figure 6 - one column

Figure 7 - two column 


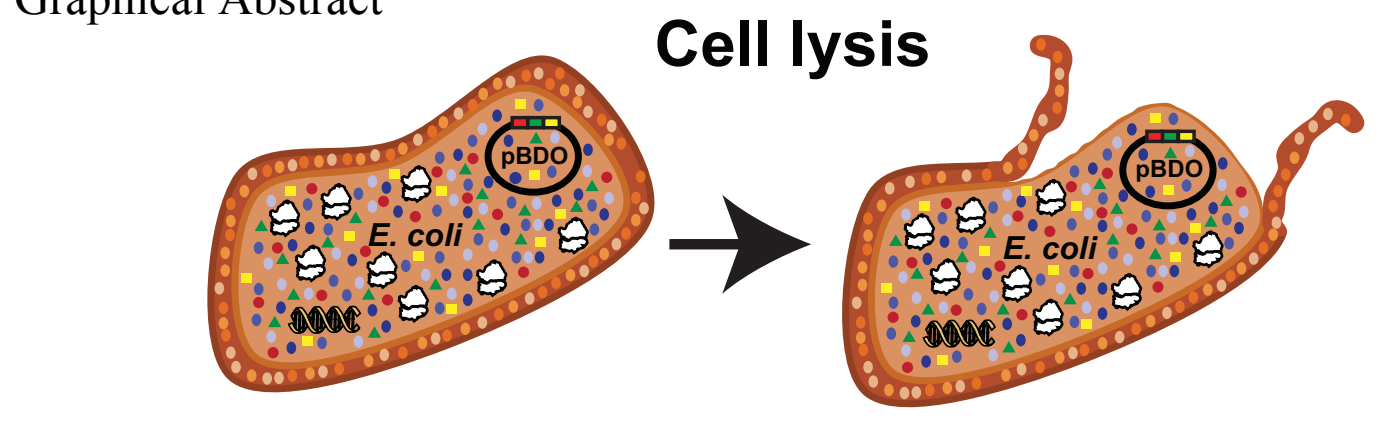

Genomic DNA

PBDO Plasmid encoding

Ribosomes

$\because$ Cellular proteins

heterologous genes ${ }^{\circ}$ Heterologous enzymes

\section{Catalyst Utilization}

Raw Materials (salts, glucose, NAD, ATP)

\section{Catalyst Synthesis}

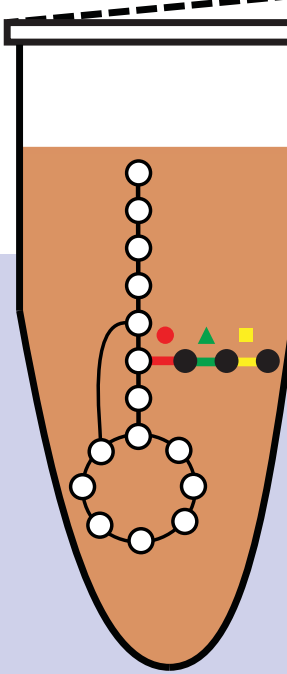

Lysate Preparation

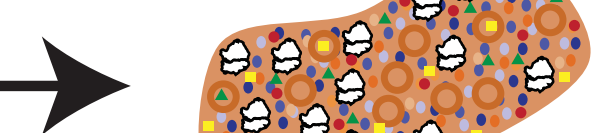

Crude E. coli Membrane vesicles lysate Integrated metabolism and cofactor regeneration 